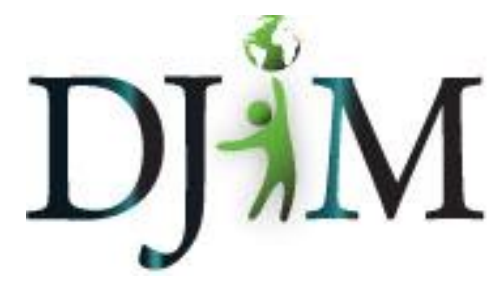

Volume 7 - Spring 2011 djim.management.dal.ca

\title{
Down the Rabbit Hole: How Cyberspace and Digital Copyright Becomes "Curiouser and Curiouser"
}

\begin{abstract}
There are various metaphors that can be used to describe and analyze the phenomena and impact of the World Wide Web on present day society. One particularly pertinent metaphor is that of Alice in Wonderland as there are a number of correlations which can be drawn between the characters within the novel and various individuals, organizations, and policies that influence the internet. As such, this paper explores the metaphor between the Internet and the characters who appear in Alice and Wonderland in terms of the characteristics they share with specific websites. These comparisons include: Alice and the user, Facebook and the Mad Hatter, and Google and the White Rabbit. By thinking of these websites in terms of their allegorical Wonderland character, it is easier to understand the effect and influence which they have upon our lives.
\end{abstract}

\begin{abstract}
About the Author(s): Ariel Kleber is an MLIS Candidate, May 2011, originally from a small town in Ontario by way of Montreal. Before beginning her Bachelor of Arts in English Literature and Professional Writing from Concordia University, Ms. Kleber worked for plane tickets to interesting and far off places.

Believing that everyone should have story time at least three times a week Ms. Kleber is focusing on Children and Young Adult resources. A strong literacy advocator, Ms. Kleber is also involved with Librarians Without Boarders and hopes to be able to use her enthusiasm and generosity of spirit to further the development of literacy within communities at home as well as abroad.
\end{abstract}


I imagine that right now, you're feeling a bit like Alice. Hmm? Tumbling down the rabbit hole?

After this, there is no turning back. You take the blue pill - the story ends, you wake up in your bed and believe whatever you want to believe. You take the red pill - you stay in Wonderland and I show you how deep the rabbit hole goes.

Morpheus, The Matrix (Berman, 1999)

The expression "down the rabbit hole" was often used to describe the phenomena of the World Wide Web in the mid-90s. However, this allusion to Wonderland is perhaps more apt today than it ever was in the past. When the Internet was new, this description alluding to the changeable atmosphere of Wonderland was fitting. However, with the development of Web 2.0, the allegory can be taken further. Now the characters in Alice in Wonderland provide a pertinent allegory to understanding the characteristics of the Internet, particularly regarding current heavyweight websites, not simply the wonder of the Wonderland environs. In this paper I will explore this allegory by examining characters who appear in Alice in Wonderland in terms of the characteristics they share with certain websites.

\section{Alice in Wonderland \& Cyberspace}

In an attempt to scrutinize the Internet, analysts took to closely following the manoeuvres of every Internet player-from the Marc Andreessens to the Bill Gateses-to gain some insight into the future of the Net. In doing so, we discount-or prefer to ignore-the distinct possibility that Webpreneurs are, to some degree, making it up as they go along. (Vernadakis, 1999, p. 48)

The inherent lack of direction and deficiency of definite rules allowed webpreneurs to push boundaries. The continuously revolutionizing coverage and development phases of the Internet are, in some ways, a direct mirror to how Lewis Carroll made up Alice in Wonderland as he went along. With every ephemeral change and innovation, conventions of privacy bend and shift. Each of us becomes "a little like Alice-talking about portals instead of rabbit holes and home pages rather than looking glasses? The surfer is a dream-child moving through a land of wonders wild and new" (Vernadakis, 1999, p. 48). In this altered reality, it is easy to forget that, as surreal as the landscape seems, it is in fact a real space with absolute consequences. These consequences are, at once, severe and intangible, and though they pose serious trepidation, they often feel too removed to warrant immediate concern. When one is tagged in an unflattering photo on Facebook, the repercussions of this act may not be immediately tangible. To a potential employer, however, this same photograph could represent a multitude of questions regarding the suitability of a potential hire. As Carroll adroitly illustrates in Wonderland, things have the ability to get "curiouser and curiouser" while at the same time maintaining a semblance of sense. Likewise, "[c]yber history will continue to write itself, in ways that may not always be predictable" (Vernadakis, 1999, p. 48). Vernadakis' 
astute comment of cyber history and the Internet getting "curiouser and curiouser" in 1999 has, in many ways, become our societal norm. In fact, as time passes and the Internet continues to develop, shifting and coalescing into a constantly changing entity "[l]ike Alice in Wonderland, the almost-2 $1^{\text {st }}$-century Nethead is plunging headlong down a rabbit hole towards Wired World" (Lewis, 1996, p. 17). Much as Alice is the constant amidst the inconsistency of Wonderland, the user is the constant in the inconsistency of the Internet. More than a decade later the Web-as-Wonderland metaphor still holds, yet what has become "curiouser and curiouser" is not only how the user interacts with the Internet as a whole, but also how the Internet now interacts with the user.

\section{Alice: The User}

Where Alice attempted to navigate the changeable Wonderland, so do we, the user, attempt to navigate the Internet. Like Alice, we innately believe the world should exist as a relatively ordered and stable place, but the Internet and Wonderland challenges this perception. Alice's approach to Wonderland is largely a study of humanity, so too should we, the user, approach the Internet. In a world where almost unlimited access is only a few mouse clicks away, our perception of information, as well as our perception of inaccessibility or of taboo subject matter is strongly affected. We surf often with little attention paid to the material that we are engaged with, information which in the non-cyber world we may strongly eschew. Alice's Victorian virtue and good manners ensure she is relatively unchanged in a changeable place; our own code of behaviour is often not so upright. In a study conducted by Ciber, leading Information Science and Media Studies experts questioned a variety of myths concerning the Google Generation. Ciber found that the Google Generation is also the "cut-and-paste generation" where Google provides the answer and plagiarism is not only increasingly prevalent, but is also not always recognized as problematic (Rowlands, et al., 2008, p. 300).

Alice is demanding. She demands to be heard, she demands the Wonderland creatures display good manners, and she demands a variety of other trifles from almost all of the characters. Alice's constant demands could be seen as similar to our demand for further, faster, and fluid access. The further Alice ventures into Wonderland, the tighter she holds to the ideals of her world. Similarly, the further we venture into the Internet, the more we demand of applications, of webpages, of databases, of search engines, and of entertainment.

Correspondingly, one can draw similarities between Alice's determination, as she "flaunts her limited information base with anyone who will listen" (SparkNote, 2005) and the tenacity of anyone with Internet access becoming a topic expert because of information available on Wikipedia. While Alice's perceptions of class, intelligence, logic, good manners, and social order are all challenged during her time in Wonderland, so, too, are the Internet users' perceptions challenged, whether actively or inactively. Access to global media and the huge variety of information available is beginning to ensure that global frontiers are decreasing as 
cybernetic prevalence increases. The more boundaries that Internet access tests, the fewer that will continue to exist.

\section{The White Rabbit: Google}

The White Rabbit, the often frenetic and frequently harried creature who initially directs Alice to Wonderland, is frenzied, fearful, and frequently pugnacious. The White Rabbit, in many ways, acts to guide Alice through Wonderland; his appearances always serve to reassert her path through the Wonderland realm, as it is always the White Rabbit she chooses to follow. Similarly, Google has become the entity that serves to help us navigate the Internet. All powerful, far-reaching, and well-connected, the White Rabbit can enter and leave Wonderland at will, is known by everyone in Wonderland, and serves as the trumpeter to the Queen. The Google family of web programs, perhaps most notably Google Search, Gmail, Google Docs, and Google Scholar, are all integrated uncompromisingly ensuring the Google presence. While the White Rabbit panders to the Queen of Hearts, this is not strictly speaking the servile nature of Google to Wikipedia. However, Wikipedia is often the top returned result in a Google search (Duddy, 2009). Google has, of course, aggressively cornered several Internet markets with interconnecting service. Today, "89 per cent of college students use search engines to begin an information search (while only 2 per cent start from a library web site)" (Rowlands, et al., 2008, p. 292). Ciber, which conducted in depth research into Internet usage and the so-called "Google Generation" concluded that:

[y]oung people have unsophisticated mental maps of what the Internet is, often failing to appreciate that it is a collection of networked resources from different providers. As a result, the search engine, whether Yahoo! or Google, becomes the primary brand that they associate with the Internet. Many young people do not find library-sponsored resources intuitive and therefore prefer to use Google or Yahoo! instead: these offer a familiar, if simplistic solution, for their study needs. (Rowlands, et al., 2008, pg. 296)

In essence, Google has become a one-stop shop for Internet research and is almost frenetic in its multi-use; this is another similarity to the White Rabbit, who serves as multiple roles to multiple people.

While Google may currently be many things to many people, Facebook is starting to move into that versatile territory. A recent 60 Minutes interview with Mark Zuckerberg illustrates this point. Facebook has successfully recruited 10 high-level Google employees, including Google Maps creator, Lars Rasmussen, and former VP of Global Online Sales and Operations Google, Sheryl Sandberg (Fager, 2010). Facebook even poached Google cafeteria chef, Josef Simone (Fager, 2010). Google has retaliated by increasing the salaries of its high level employees, attempting to keep them in house and away from the allure of Facebook.

\section{The Mad Hatter: Facebook}

Down the Rabbit Hole: How Cyberspace and Digital Copyright... 4 
The Mad Hatter is "a small, impolite hatter who lives in perpetual tea-time. The Mad Hatter enjoys frustrating Alice" (SparkNote, 2005). The first thing which the Mad Hatter says to Alice is "'Your hair wants cutting,' .... He had been looking at Alice for some time with great curiosity" (Carroll, 2010, p. 41). The way in which Alice feels towards the Hatter, simultaneously curious and repulsed, is not dissimilar to the love-hate relationship that many users experience in the vacuum of Facebook. While "[s]ocial media, in particular, enables individuals to connect with multiple audiences on online social planes that are neither conventionally public, nor entirely private" (Papacharissi, 2010), Facebook exemplifies the unconventional. It also pushes the boundaries of the public and the private sphere in a way that has never before been experienced, similar to how the Mad Hatter upsets Alice's notions of propriety and manners.

The Mad Hatter's conception of propriety and manners greatly differs from that of Alice; however, by the end of teatime many of Alice's own perceptions have begun to change, so too with Facebook and Facebook users. Privacy in the digital era is beginning to become ephemeral, particularly regarding the changing of Facebook's privacy policy, where default settings are set to "share" rather than "private," which "prompts users to be more public with their information" (Papacharissi, 2010). Facebook CEO, Mark Zuckerberg, purports that "Facebook is designed to increase the efficiency and transparency of communication" (Raynes-Goldie, 2010). Transparency of communication can refer to "voluntary selfsurveillance and full disclosure of a user's activities to everyone on their Friends list, from a significant other, to a boss, to a long lost childhood friend" (Raynes-Goldie, 2010).

Mischievous, though relatively well intentioned, the Mad Hatter's inability to be clear, honest, and less than barmy leads to distinct questions of credibility. Alice questions the Hatter's sincerity, much in the way that activist groups like the Electronic Privacy Information Center (EPIC) question Facebook's transparency. EPIC went so far as to claim that "Facebook pulled a 'privacy bait and switch,' getting users to provide personal information under one set of privacy terms, then modifying their privacy policies" (Chittal, 2010). We, the users, are trading our right to privacy:

in exchange for access to social services, [b]yte by byte, our personal information is exchanged as currency, to gain digital access to friends. In this manner, personal information is commercialized into the public realm, with little input from the individual in the process" (Papacharissi, 2010).

\section{The Queen of Hearts \& Red Queen: Wikipedia}

Wikipedia can be seen through the combined lens of the Queen of Hearts and the Red Queen, the former an obstacle hampering Alice's progress through Wonderland, while the later hampers Alice's progress across the chessboard of Through the Looking Glass. The "Queen [of Hearts] is severe and domineering, continually screaming for her subjects to be beheaded" (SparkNotes, 2005), and she is "not as concerned with nonsense and perversions of logic as 
she is with absolute rule and execution" (SparkNotes, 2005). When the Queen of Hearts happens upon three gardeners painting her roses, one gardener tries to explain:

'May it please your Majesty,' said Two, in a very humble tone, going down on one knee as he spoke, 'we were trying -' but before he can manage to get out the story, the Queen of Hearts cuts him off 'I see!' said the Queen, who had meanwhile been examining the roses. 'Off with their heads!' and the procession moved on. (Carroll, 2010, p. 54)

While Wikipedia is not nearly as bloodthirsty, nor as resolute as the Queen of Hearts appears to be, there are still similarities. The Queen of Hearts jumps to conclusions, similar to the "truth" of Wikipedia articles. The underlying reality is that she does not execute anyone who she sentences to death, 'reinforce[ing] the fact that the Queen of Hearts' power lies in her rhetoric" (SparkNotes, 2005). Similarly the power of Wikipedia also lies in its language. Written by the global population for the use of the global population, Wikipedia's style and idioms ensure comprehension of even the most complex idea or historical event, turning lengthy discourses into easy to manage articles.

Easy to manage articles could also draw a correlation between Wikipedia and the Red Queen. The Red Queen has a habit of drawing to mind a stern Victorian-era governess: strict, proper, but ultimately benign. When Alice first encounters the Red Queen, the Queen asks "Where do you come from? ... And where are you going? Look up, speak nicely, and don't twiddle your fingers all the time" (Carroll, 2010, p. 16 ). The disposition of governess continues in their conversation when Alice struggles to explain her presence, "I don't know what you mean by your way,' said the Queen: 'all the ways about here belong to me -- but why did you come out here at all?' she added in a kinder tone. 'Curtsey while you 're thinking what to say, it saves time" (Carroll, 2010, p. 16). Wikipedia, like the governess, has a set task, is meant to be an entity that takes the job seriously, and is talented enough to explain difficult topics while still maintaining some thread of complex integrity. Despite all this, however, Wikipedia could be seen as a prime example of argumentum ad populum. In the article "It's on Wikipedia, so it must be true," Ahrens uses the example of Stephen Colbert to illustrate this point. During an episode of The Colbert Report, political comedian Stephen Colbert "urged viewers to take part in rewriting history and fact .... Naturally, enough people obeyed Colbert to crash Wikipedia's servers" (Ahrens, 2006). As always, this is the problem with a site of this nature. The information is broad in scope as well as spectrum because so many people can contribute; at the same time the information is questionable and biased, because so many people can contribute.

\section{The Cheshire Cat: Jennifer Stoddart}

The Cheshire Cat is of Wonderland, but is also outside Wonderland. Unthreatened by the Queen of Heart's irrationality, or the Hatter's madness, the Cheshire Cat "maintains a cool, 
grinning outsider status" (SparkNotes, 2005). During Alice's first interaction with the Cheshire Cat they discuss directions and madness:

'Would you tell me, please, which way I ought to go from here?'

'That depends a good deal on where you want to get to,' said the Cat.

'I don't much care where--' said Alice.

'Then it doesn't matter which way you go,' said the Cat.

'--so long as I get SOMEWHERE,' Alice added as an explanation.

'Oh, you're sure to do that,' said the Cat, 'if you only walk long enough.' (Carroll, 2010, p. 41)

The Cheshire Cat is able to provide Alice with valuable insight into the inner workings of the Wonderland community; explaining to Alice the madness that will continue to surround her whilst there. The Cheshire Cat serves simultaneously as a guide, a translator, and a defender of sorts.

Jennifer Stoddart, the Canadian Privacy Commissioner also acts as guide cum protector. The Privacy Commissioner investigates complaints, monitors proposed legislation, reviews authorised data matching programs, and promotes understanding of privacy principles (Treasury Board, 2003). In short, the Privacy Commissioner "has broad powers to enquire into any matter if she believes that the privacy of the individual is being, or is likely to be, infringed" (Privacy Commissioner, n.d.).

In Wonderland, Alice has the Cheshire Cat to serve as guide and protector, slight though those roles may be. Canadians have the Privacy Commissioner. The Privacy Commissioner in addition to various privacy acts works in the defence of the user, such as the American Children's Online Privacy Protection Act (COPPA) and the Financial Modernization Act (FMA) which "pertain to the [American] government's use of personal information (Papacharissi, 2010). FMA "specifies that financial institutions must inform customers about their privacy practices, but provides limited control to consumers regarding the use and distribution of personal data" providing an attempt at consumer protection but is deficient because the act still requires proactively on the part of the consumer. COPPA allows for stringent policy, which largely impedes corporations from directing online marketing approaches at individuals under the age of 13 (Papacharissi, 2010). As Papacharissi writes:

A regulatory framework must define, protect, and educate about "the right to an inviolate personality" online. Ultimately, because online environments work globally, educating the public about the "right to be let alone," online, is an important part of crafting a regulatory solution that ensures privacy becomes a public good, for global users (Papacharissi, 2010). 
In 2008, the Canadian Internet Policy and Public Interest Clinic (CIPPIC) filed a complaint with the Office of the Privacy Commissioner (OPC) against Facebook. This complaint cited breaches of the Canadian Personal Information Protection and Electronic Documents Act. Elizabeth Denham, the Assistant Privacy Commissioner of Canada, found a number of these complaints to be substantiated (Denham, 2009). One particular point which Denham found particularly disquieting was that "Facebook did not do enough to ensure users granted meaningful consent for the disclosure of personal information to third parties and did not place adequate safeguards to ensure unauthorized access by third party developers to personal information" (Denham, 2009). Facebook's privacy settings give Facebook the right to "[d]o anything they want with your content. Forever" (Walters, 2009). Walters continues to explain that "[y]ou may remove your User Content from the Site at any time. If you choose to remove your User Content, the license granted above will automatically expire, however you acknowledge that the Company may retain archived copies of your User Content" (2009). These are the very troubling points which the OPC wished Facebook to address. Without the Privacy Commissioner to step in on behalf of Canadians, it is unlikely that Facebook would have conceded any points about the state of its privacy settings. A number of cases had been brought against Facebook prior to the Privacy Commissioner's inquest, but most never appeared before a judge because they simply did not carry the weight of a country behind them (Denham, 2009).

As Raynes-Goldie points out, "[t]o an outsider, sharing personal information on Facebook can seem like a ridiculous thing to do. Why would anyone compromise their privacy in such a manner? This question has puzzled both the mass media and academics alike" (2010). This pattern is not dissimilar to the bewilderment which Alice feels regarding the increasing absurdity of Wonderland.

Though the similarities between the Mad Hatter and Facebook are not simply related to interpretations of privacy and propriety, time, or rather the squandering of time, also plays a huge part in the parallelism. In Alice in Wonderland, the Hatter explains to Alice why he and the March Hare celebrate a perpetual tea time. During a celebration, the Hatter was playing for the Queen, 'Well, I'd hardly finished the first verse,' said the Hatter, 'when the Queen jumped up and bawled out, 'He's murdering the time! Off with his head!'” (Carroll, 2010, p. 47). In recognition of the Hatter's near decapitation, Time halts himself, keeping the Mad Hatter and the March Hare stuck at 6:00, tea time, forever. Not unlike the habit of many a student to "murder the time" on Facebook rather than working on the paper which needs writing, the Queen of Hearts accuses the Mad Hatter of being a perpetual time waster. Facebook is well known by this same epitaph. Director (Mobile) of Facebook, Henri Moissnac, stated that "[e]veryday, people spend five billion minutes on Facebook, making it one of the top three properties on the Internet (there are 525,600 minutes in a year)" (The world's biggest waste of time, 2009). MyJobGroup.co.uk made headlines in August for "calculating that workday use of Facebook, Twitter, et al., are robbing the British economy of $\$ 22$ billion a year in employee 
productivity" (Dumenco, 2010). Considering that the population density for Facebook saturation in the United Kingdom is currently two-thirds of Canada's, it would be interesting to know how many billion time-dollars Canadians waste annually.

\section{The Red King \& King of Hearts: Canada's Internet Copyright law and Bill C-32}

The King of Hearts is the "coruler of Wonderland. The King is ineffectual and generally unlikeable, but lacks the Queen's ruthlessness and undoes her orders of execution" (SparkNotes, 2005). The first thing which the King of Hearts utters is "Consider, my dear: she is only a child!" (Carroll, 2010, p. 54), timidly to his wife when the Queen of Hearts calls for Alice's head. The next moment the King of Hearts has an interaction with Alice and the Cheshire Cat, the King states that he does not "like the look of it at all ... however, it may kiss my hand if it likes" (Carroll, 2010, p. 57). The King is referring to the Cheshire Cat as "it" and "it" does not like this treatment, and tells the King of Hearts as much. At this point the King responds with 'DDon't be impertinent,' said the King, 'and don't look at me like that!' He got behind Alice as he spoke" (Carroll, 2010, p. 57). The King of Hearts uses Alice as a shield before using what he knows of the Queen of Hearts' volatile nature to take revenge on the Cheshire Cat. Current Canadian Internet copyright laws have this same bullying, hard-headed, and heavy-handed approach. The key similarity here is the broad-spectrum ineffectually of outdated Canadian copyright law and policy. Murray considers the:

rhetoric of "protection" ubiquitous in Canadian discussions of copyright policy, and identifies among the various uses of the term both a problematic assumption that protection is or should be the primary function of copyright, and overblown claims about copyright's power to protect Canadian culture and creators. These "common sense" ideas, fostered by rights-holder lobbies, emerge out of a peculiar Canadian history of cultural nationalism(s), but they may not promote the interests of Canadians (Murray, 2004).

Incongruously, to the "fear for their cultural sovereignty" Canada's Internet copyright legislation largely looks to America for direction when discussing copyright law. Similarly, this copyright law, last visited in 1997, is so woefully out of date that any application of it in today's media and information rich settings is almost laughable. In 1997, Google was a year away from launching, Wikipedia would be launched two years after that, YouTube would launch in early 2005, and Facebook in 2006, and in the ten years between 1997 and 2007, Internet usage would jump from 280 million to 1.1 billion (Todaro, 2008). The advancements in technology, as well as the increase in users leaves the Canadian laws sorely dated.

The Red King does not move, he is stagnant; in fact, he is asleep almost throughout the story; a rather apt similarity to a law which has not been revisited since 1997. In fact, Bill C-32, 
though past its second reading, is so lax and soporific that the Canadian Internet Policy and Public Interest Clinic (CIPPIC) website FAQ section has yet to be updated. Instead, for active information one must consult the blog of Michael Geist, Canadian Research Chair in Internet and E-commerce Law. Geist writes that the new Bill C-32 does address some of C-31's shortcomings by including a 'YouTube exception' that grants Canadians the right to create remixed user generated content for non-commercial purposes under certain circumstances (Geist, 2010). Geist further notes that while $C$-32 is "still not as good as a flexible fair dealing provision, the compromise is a pretty good one" should the drafting include "notice-and-notice for Internet providers, backup copying, and some important changes to the statutory damages regime for non-commercial infringement and there are some provisions worth fighting to keep" (Geist, 2010). Cory Doctorow, in an article he wrote for The Guardian, succinctly conveys the problems with Canadian copyright law:

there have been two recent attempts to reform Canadian copyright law. Both failed, due in large part to an unwillingness on the part of lawmakers to conduct public review or consultation on their proposals (though they were happy to have closed-door meetings with lobbyists representing offshore entertainment giants). The minority Tory government is now fielding a third attempt, called Bill C32 (Canadian bills have much less interesting names than their UK counterparts; here, we'd probably call it The Enhancement of Digital Life Through Extreme Punishments for Naughty Pirates Bill of 2010). (Doctorow, 2010)

The humour which Doctorow uses to offset the problem jibs at both the Canada and the British, yet it does illustrate the problem with the system. Canadians need to be able to take an active part in the creation of the laws that govern copyright in our country. Top down governance is no longer as effective a system of government, not when a large portion of the population is educated and an even higher percentage are active Internet and social media users. We, the people, have to discuss what we would like to be included in copyright law, as well as what should be deemed fair use. Doctorow feels emphatically that the population has the right to voice an opinion:

More than 8,300 Canadians filed comments in the consultation, and they spoke with near unanimity: "We don't want a US-style copyright regime.".... Only 46 of the 8,306 commenters thought otherwise. These 46 commenters advocated replicating America's failed experiment in Canada; everyone else thought the idea was daft. You'd think that with numbers like 46:8260, the government would go with the majority, right? Wrong (Doctorow, 2010).

Doctorow states in his article that Minister of Industry Tony Clement and Minister of Heritage James Moore, who were tasked with drafting the new copyright bill, did indeed adopt the American standpoint regarding digital locks, without any of the safeguard systems which the 
Americans put into place regarding potential exemptions (Doctorow, 2010). Currently in its second reading, we shall see what becomes of Bill C-32.

\section{Conclusion}

The Internet has been in a state of trial-and-error since its inception. The ebb and flow of data and information has become increasingly difficult to patrol and monitor, and the demand for fluid, uninhibited access is a challenge for policy makers. However, when the population takes no part in the creation of the laws by which they will be governed, one can only expect that these policies will not adequately reflect the needs of the nation. The aim of this paper is to shed light upon the yawning cavern of the Internet and provide some insight into a way users can interact with, or at least be aware of the various individuals, organizations, and policies that influence Internet usage. This is a tool, a road map, which does not attempt to pose the solutions needed for restructuring.

Wonderland continues to be "curiouser and curiouser" and so too does the Internet. By thinking of these websites in terms of their allegorical Wonderland character, it is easier to understand the affect and influence which they have upon our lives. It is also possible to step back from them constructively and assign a more suitable role to them. As we continue to traipse "down the rabbit hole," there is no way to wake up next to Dinah and realize it was all a peculiar dream. Web 2.0 consumers need to be aware and wary of the current legislature and what privacy terms and conditions exist in order to protect themselves, lest they become unwary fodder for the Walrus and the Carpenter. 


\section{References}

Ahrens, F. (2006, August 6). It's on Wikipedia, so it must be true. The Washington Post.

Retrieved from http://www.washingtonpost.com/wp-

dyn/content/article/2006/08/05/AR2006080500114.html

All Facebook. (2010). Facebook demographics: Countries by Facebook market saturation. Retrieved from http://www.allfacebook.com/facebook-demographics-countrysaturation-2009-01

Berman, B. (Producer), Wachowski, A., \& Wachowski, L. (Directors). (1999). The Matrix [Motion picture]. Sydney, Australia: Groucho II Film Partnership, Silver Pictures, Village Roadshow, \& Warner Bros. Pictures.

Canadian Internet Policy and Public Interest Clinic. (2010). Bill C-32: Copyright Bill 2010 F.A.Q. Retrieved from http://www.cippic.ca/bill-c-32-copyright-bill-2010/\#F.A.Q.

Carroll, Lewis. (2010). Alice in Wonderland. Retrieved from http://books.google.ca/books?id=685AudWiwvUC\&printsec=frontcover\&dq=Through +the+looking+glass\&hl=en\&ei=sXWGTbu8Lof2gAfHs6DWCA\&sa=X\&oi=book_result \&ct=result\&resnum=4\&ved=0CEQQ6AEwAw\#v=onepage \&q=Curtsey\%20while\%20 $\& \mathrm{f}=\mathrm{false}$

Chittal, N. (2010). The case for staying with Facebook. American Prospect. Retrieved from http://www.prospect.org/cs/articles?article=the_case_for_staying_with_facebook

Denham, E. (2009, July). Report of findings into the complaint filed by the Canadian Internet policy and public interest clinic (CIPPIC) against Facebook Inc. Under the personal information and electronic documents act. Retrieved from http://www.priv.gc.ca/cfdc/2009/2009_008_0716_e.pdf

Doctorow, C. (2010, June 29). Canada's copyright laws show Britain's digital legislation is no exception. The Guardian. Retrieved from http://www.guardian.co.uk/technology/2010/jun/29/canada-copyright-digitaleconomy? INTCMP $=\mathrm{SRCH}$

Duddy, C. (2009). A personal perspective on accessing academic information in the Google era, or 'How I learned to stop worrying and love Google'. In Proceedings of the 32nd UKSG Conference, March/April 2009. Torquay, UK: Oxford. 
Dumenco, S. (2010). Game theory: How (and why) Facebook, Twitter, etc., became recess for grown-ups. Advertising Age, 81(30).

Fager, J. (Executive Producer). (2010, December 5). 60 Minutes [Television broadcast]. Washington, DC: CBS News.

Geist, M. (2010, June 2). The Canadian copyright bill: Flawed but fixable [Web-log message]. Retrieved from http://www.michaelgeist.ca/content/view/5080/125/

Google. (2009). Moon viewing day, Tsukimi - Japan. Retrieved from http: http://www.google.com/logos/logos09-4.html

Lewis, T. (1996). Alice in wired world: Wonderland or wasteland. Computer, 29(7), 17-21.

Lindsey, D. (2010). Evaluating quality control of Wikipedia's feature articles. First Monday, 15(4). http//www.uic.edu/htbin/cgiwrap/bin/ojs/index.php/fm/article/view/2721/2 482

Murray, L. J. (2004). Protecting ourselves to death: Canada, copyright, and the Internet. First Monday, 9(10). Retrieved from http://firstmonday.org/htbin/cgiwrap/bin/ojs/index.php/fm/article/view/1179 $/ 1099$

Papacharissi, Z. (2010). Privacy as a luxury commodity. First Monday, 15(8). http://firstmonday.org/htbin/cgiwrap/bin/ojs/index.php/fm/article/view/3075 $/ 2581$

Privacy Commissioner. (n.d.). Frequently asked questions. Retrieved from http://privacy.org.nz/frequently-asked-questions/\#what-does-the-privacycommissioner-do

Raynes-Goldie, K. (2010). Aliases, creeping, and wall cleaning: Understanding privacy in the age of Facebook. First Monday, 15(1). http://firstmonday.org/htbin/cgiwrap/bin/ojs/index.php/fm/article/view/2775 12432

Rowlands, I., Nicholas, D., Williams, P., Huntington, P., Fieldhouse, M.... Tenopir, C. 
(2008). The Google generation: the information behaviour of the researcher of the future.

Aslib Proceedings, 60(4), 290-310.

SparkNotes. (2005). SparkNote on Alice's Adventures in Wonderland. Retrieved from http://www.sparknotes.com/lit/alice/

Todaro, M. (2008). Internet Marketing Revealed. Retrieved from http://www.migueltodaro.com/img_2/internet_timeline.jpg

Treasury Board of Canada Secretariat. (2003). What does the Office of Privacy Commissioner (OPC) of Canada do? Retrieved from http://www.tbs-sct.gc.ca/pgol-pged/piatppfefvp/course $1 / \bmod 5 / \bmod 5$-3-eng.asp

Vernadakis, G. (1999). Alice's adventures in cyberspace. Inter@ctive Week, 6(3), 48.

Walters, C. (2009). Facebook's new terms of service: "We can do anything we want with your content. Forever. The Consumerist. Retrieved from http://consumerist.com/2009/02/facebooks-new-terms-of-service-we-can-doanything-we-want-with-your-content-forever.html

The world's biggest waste of time. (2009). Business Today, 18(20), 132.

Reference follows APA $6^{\text {th }}$ edition with a hanging indentation of 0.75 ". The spacing is still 1.15 . text is 12 pt Arial, black, and 1.15 spacing. Reference follows APA $6^{\text {th }}$ edition with a hanging indentation of 0.75 ". The spacing is still 1.15 . text is 12 pt Arial, black, and 1.15 spacing.

Reference follows APA $6^{\text {th }}$ edition with a hanging indentation of 0.75 ". The spacing is still 1.15 . text is 12 pt Arial, black, and 1.15 spacing. Reference follows APA $6^{\text {th }}$ edition with a hanging indentation of 0.75 ". The spacing is still 1.15 . text is 12 pt Arial, black, and 1.15 spacing.

Reference follows APA $6^{\text {th }}$ edition with a hanging indentation of 0.75 ". The spacing is still 1.15 . text is 12 pt Arial, black, and 1.15 spacing. Reference follows APA $6^{\text {th }}$ edition with a hanging indentation of 0.75 ". The spacing is still 1.15 . text is 12 pt Arial, black, and 1.15 spacing.

Reference follows APA $6^{\text {th }}$ edition with a hanging indentation of 0.75 ". The spacing is still 1.15 . text is 12 pt Arial, black, and 1.15 spacing. Reference follows APA $6^{\text {th }}$ edition with a 
hanging indentation of 0.75 ". The spacing is still 1.15 . text is 12 pt Arial, black, and 1.15 spacing.

Reference follows APA $6^{\text {th }}$ edition with a hanging indentation of 0.75 ". The spacing is still 1.15 . text is 12 pt Arial, black, and 1.15 spacing. Reference follows APA $6^{\text {th }}$ edition with a hanging indentation of 0.75 ". The spacing is still 1.15 . text is 12 pt Arial, black, and 1.15 spacing.

Reference follows APA $6^{\text {th }}$ edition with a hanging indentation of 0.75 ". The spacing is still 1.15 . text is 12 pt Arial, black, and 1.15 spacing. Reference follows APA $6^{\text {th }}$ edition with a hanging indentation of 0.75 ". The spacing is still 1.15 . text is 12 pt Arial, black, and 1.15 spacing.

Reference follows APA $6^{\text {th }}$ edition with a hanging indentation of 0.75 ". The spacing is still 1.15 . text is 12 pt Arial, black, and 1.15 spacing. Reference follows APA $6^{\text {th }}$ edition with a hanging indentation of 0.75 ". The spacing is still 1.15 . text is 12 pt Arial, black, and 1.15 spacing.

Reference follows APA $6^{\text {th }}$ edition with a hanging indentation of 0.75 ". The spacing is still 1.15 . text is 12 pt Arial, black, and 1.15 spacing. Reference follows APA $6^{\text {th }}$ edition with a hanging indentation of 0.75 ". The spacing is still 1.15 . text is 12 pt Arial, black, and 1.15 spacing. 